\title{
Experimental induction of biological tags in otoliths of 0-group plaice Pleuronectes platessa by starvation, temperature, and UV-B radiation
}

\author{
Rüdiger Berghahn ${ }^{1}$, Maria Karakiri ${ }^{2}$ \\ ${ }^{1}$ Institut für Hydrobiologie und Fischereiwissenschaft der Universität Hamburg, Elbelabor, Ausrüstungskai 6, \\ D-2000 Hamburg 50, Germany \\ ${ }^{2}$ Biologische Anstalt Helgoland, Notkestra6e 31, D-2000 Hamburg 52, Germany
}

\begin{abstract}
Characteristic hyaline zones in otoliths of 0-group plaice can be induced artificially by rapid rises in water temperature, by high cumulative doses of UV-B radiation, and by starvation. This is evidenced by backdating based on SEM microstructure analysis. Since early postlarval plaice can be exposed to similar conditions in the main nursery grounds, such formations in the otoliths of specimens from the Wadden Sea most probably result from environmental stress during and after the pooldwelling mode of life.
\end{abstract}

\section{INTRODUCTION}

During a 10 yr field investigation, one or more pronounced hyaline rings (transparent when viewed on a dark background under a stereomicroscope) could regularly be observed in the otoliths of a large part of the 0 -group plaice population from the North Frisian Wadden Sea, Germany (Berghahn 1984). Daily increment readings employing light microscopy and scanning electron microscopy (SEM) suggested that these formations result from extreme environmental situations (Berghahn 1989) occurring when newly settled plaice remain in residual waters on the tidal flats during low tide (Bergman et al. 1976).

In order to elucidate the causes of such hyaline formations, laboratory-reared plaice were exposed to stressful conditions similar to those observed in the North Frisian Wadden Sea. The effects of a rapid rise in water temperature, high cumulative doses of UV-B radiation, and starvation on otolith microstructure were investigated.

\section{MATERIAL AND METHODS}

Plaice Pleuronectes platessa L. eggs were collected during surveys in the southern North Sea and incubated under constant laboratory conditions $\left(\mathrm{T}\right.$ : $5^{\circ} \mathrm{C}$,
S: $30 \mathrm{ppt}, \mathrm{L} / \mathrm{D}: 12 / 12$ ). After hatching, batches of larvae of the same age were reared to the bottom-living stage in $15 \mathrm{l}$ glass containers under constant conditions ( $\mathrm{T}$ : $10^{\circ} \mathrm{C}, \mathrm{S}: 30 \mathrm{ppt}, \mathrm{L} / \mathrm{D}: 16 / 8$ ). Newly hatched Artemia nauplii were supplied ad libidum and water was exchanged daily. After the transition to the bottomdwelling mode of life, frozen Mysidacea and chopped herring meat were supplied daily together with Artemia nauplii.

All experiments were carried out with plaice which had just completed the transition to the bottom-dwelling stage (total length 12 to $14 \mathrm{~mm}$ ). The experiments were conducted in shallow tanks attached to the seawater circulation system of the Biologische Anstalt Helgoland, Hamburg (Germany). Almost $90 \%$ of the laboratory-reared plaice were pseudoalbinos (Shelbourne et al. 1963). The abiotic factors tested were similar to the extreme conditions reported from the Wadden Sea at the time of larval settlement (Berghahn 1983), when the majority of settlers occur in residual water on tidal flats during low tide (Bergman et al. 1976, Berghahn 1984).

Temperature. In 9 out of 10 trials, groups of young plaice were subjected to gradual temperature increases from 10 or $15^{\circ} \mathrm{C}$ up to 24,25 or $27^{\circ} \mathrm{C}$. The tenth group served as control for all experiments described in this paper. Duration of exposure to the final temperature level varied among the experimental groups (Table 1). 
Table 1. Experimental protocol for testing effects of rapid temperature increase on the otolith microstructure of juvenile plaice. $T^{\circ} \mathrm{C}$ (1): initial acclimation temperature; $\mathrm{T}^{\circ} \mathrm{C}$ (2): $\max -$ imum temperature during exposure; R: duration of temperature increase $(\mathrm{h})$; $\mathrm{E}$ : exposure time to maximal temperature $(h)_{i} T^{\circ} \mathrm{C}(3)$ : rearing temperature after exposure

\begin{tabular}{|ccccccc|}
\hline $\begin{array}{c}\text { Expt } \\
\text { group }\end{array}$ & $\begin{array}{c}\text { Fish } \\
(\mathrm{n})\end{array}$ & $\begin{array}{c}\mathrm{T}^{\circ} \mathrm{C} \\
(1)\end{array}$ & $\begin{array}{c}\mathrm{T}^{\circ} \mathrm{C} \\
(2)\end{array}$ & $\mathrm{R}$ & $\mathrm{E}$ & $\begin{array}{c}\mathrm{T}^{\circ} \mathrm{C} \\
(3)\end{array}$ \\
\hline 1 & 30 & 10 & 27 & 4 & 1 & 10 \\
2 & 8 & 10 & 24 & 3 & 1 & 15 \\
3 & 8 & 10 & 24 & 3 & 2 & 15 \\
4 & 8 & 10 & 24 & 3 & 3 & 15 \\
5 & 10 & 10 & 25 & 3 & 2 & 15 \\
6 & 10 & 10 & 25 & 3 & 5 & 15 \\
7 & 10 & 15 & 27 & 3 & 1 & 15 \\
8 & 10 & 15 & 27 & 3 & 2 & 15 \\
9 & 10 & 15 & 27 & 3 & 5 & 15 \\
10 & 10 & 10 & 15 & 1 & $\mathrm{C}^{\mathrm{a}}$ & 15 \\
& & & & & & \\
a C: control group & & & & & & \\
\hline
\end{tabular}

Table 2. Experimental design for testing the effects of UV-B radiation on the otolith microstructure of juvenile plaice. Two replicates $(a, b)$ were exposed to each cumulative dose tested

\begin{tabular}{|ccccc|}
$\begin{array}{l}\text { Expt } \\
\text { group }\end{array}$ & $\begin{array}{c}\text { Fish } \\
(\mathrm{n})\end{array}$ & $\begin{array}{l}\text { UV-B dose } \\
\left(\mathrm{mJ} \mathrm{cm} \mathrm{cm}^{-2}\right)\end{array}$ & $\begin{array}{c}\text { Exposure } \\
\text { time (min) }\end{array}$ & $\begin{array}{c}\text { Mortality } \\
\text { rate (\%) }\end{array}$ \\
\hline $1 \mathrm{a}, \mathrm{b}$ & 20 & 50 & 28.8 & 15 \\
$2 \mathrm{a}, \mathrm{b}$ & 20 & 75 & 42.8 & 30 \\
$3 \mathrm{a}, \mathrm{b}$ & 20 & 100 & 57.7 & 65 \\
\hline
\end{tabular}

After exposure, water temperature was reduced to 10 or $15^{\circ} \mathrm{C}$ within $60 \mathrm{~min}$. All fish from the 10 trials were kept another $3 \mathrm{wk}$ under control conditions, then anaestheized in MS 222 (tricain methanosulfonate) and fixed in $96 \%$ ethanol.

$\mathrm{UV}$-B radiation. After an acclimation period of $3 \mathrm{~d}$ in a shallow tank at $15^{\circ} \mathrm{C}, 90$ young plaice were divided into 6 experimental groups (Table 2) and exposed to $U V-B$ radiation $(280$ to $320 \mathrm{~nm}$ ). Cumulative doses of $U V-B$ radiation tested were selected on the basis of previous experimental results reported by Bullock (1982). According to these findings, the epidermis of young plaice can be destroyed within $48 \mathrm{~h}$ following irradiation with $63 \mathrm{~mJ} \mathrm{\textrm {cm } ^ { - 2 }} \mathrm{UV}$-B. A Phillips lamp $40 \mathrm{~W} / \mathrm{TL} 12 \mathrm{~S}$ was used as source of UV-B radiation. The exposure time necessary to achieve the desired cumulative doses was calculated through energy measures. Calculations took account of the fact that transmission was limited to only $18 \%$ at the bottom of the experimental tank (depth $5 \mathrm{~cm}$ ) due to dissolved yellow substances in the circulating seawater.

Starvation. A group of 10 young plaice was exposed to starving conditions. Fish were transferred immediately after settlement from the rearing containers
Table 3. Pleuronectes platessa. Formation of biological tags (hyaline rings) in otoliths of juvenile plaice exposed to extreme conditions

\begin{tabular}{|c|c|c|c|c|}
\hline $\begin{array}{l}\text { Extreme } \\
\text { conditions }\end{array}$ & $\begin{array}{l}\text { Hyaline } \\
\text { rings }^{a}\end{array}$ & $\begin{array}{l}\text { Altered } \\
\text { increments } \\
(n)\end{array}$ & $\begin{array}{l}\text { Beginning of } \\
\text { alteration } \\
\text { (d) }{ }^{b}\end{array}$ & $\begin{array}{c}\text { Survival } \\
\text { rate } \\
(\%)\end{array}$ \\
\hline \multicolumn{5}{|l|}{ Temperature } \\
\hline $27^{\circ} \mathrm{C}, 1 \mathrm{~h}$ & - & - & - & 6 \\
\hline $24^{\circ} \mathrm{C}, 1 \mathrm{~h}$ & - & - & - & 100 \\
\hline $24^{\circ} \mathrm{C}, 2 \mathrm{~h}$ & - & - & - & 100 \\
\hline $24^{\circ} \mathrm{C}, 3 \mathrm{~h}$ & - & - & - & 100 \\
\hline $25^{\circ} \mathrm{C}, 2 \mathrm{~h}$ & - & - & - & 95 \\
\hline $25^{\circ} \mathrm{C}, 5 \mathrm{~h}$ & Thin & $2-3$ & 1 & 90 \\
\hline $27^{\circ} \mathrm{C}, 1 \mathrm{~h}$ & - & - & - & 95 \\
\hline $27^{\circ} \mathrm{C}, 2 \mathrm{~h}$ & - & - & - & 95 \\
\hline $27^{\circ} \mathrm{C}, 5 \mathrm{~h}$ & Thin & $2-3$ & 1 & 90 \\
\hline \multicolumn{5}{|c|}{ UV-B radiation } \\
\hline $50 \mathrm{~mJ} \mathrm{~cm}^{-2}$ & Thick & $6-7$ & 1 & 85 \\
\hline $75 \mathrm{~mJ} \mathrm{~cm}-2$ & Thick & $6-9$ & $i$ & 70 \\
\hline $100 \mathrm{~mJ} \mathrm{~cm}^{-2}$ & Thick & $6-12$ & 1 & 35 \\
\hline $\begin{array}{l}\text { Starvation } \\
\text { (7 d) }\end{array}$ & Medium & $5-6$ & $2-3$ & 100 \\
\hline Control & - & - & - & 100 \\
\hline
\end{tabular}

$\left(10^{\circ} \mathrm{C}\right)$ into a shallow tank $\left(15^{\circ} \mathrm{C}\right)$. After an acclimation period of $3 \mathrm{~d}$, fish were left without any food for $1 \mathrm{wk}$.

Examination of otoliths. Otoliths were extracted under a stereomicroscope and both left and right sagittae were examined in reflected light on a dark background. No macroscopic differences were found with regard to the aspects studied. Consequently, one otolith from each pair was mounted with Euparal on a black slide for macroscopical observation, while the other was prepared for SEM examination. For SEM microstructure analysis, otoliths were mounted with shellac on SEM stubs, ground up to the midplane and polished on a rotating glass-disc employing silicon carbide, 1 to $2 \mu \mathrm{m}$ grain size, as an abrasive (details in Karakiri \& von Westernhagen 1988), etched with $0.1 \mathrm{M}$ EDTA pH 7.4 for 2 to 3 min, dried, coated with gold and viewed in SEM. Increment analysis was carried out from SEM photographs.

\section{RESULTS}

Macroscopic examination of otoliths from newly settled plaice which had been exposed to elevated temperatures, strong UV-B radiation, or starvation revealed in most cases the formation of biological tags (Table 3) surrounding the nucleus (primordium + larval phase). Deposition of hyaline material was followed 
by opaque material deposition (Fig. 1). Hyaline rings were absent in otoliths of the control group (Fig. 1a).

SEM examination of otoliths showed that the formation of hyaline zones is due to the deposition of slightly thinner increments with an altered calcium carbonate/ otolin ratio (Fig. 2). Backdating based on increment counts revealed that the deposition of such altered increments started either on the day following exposure to extreme conditions or 1 to 2 d later (Table 3).

\section{Temperature}

A decrease in fish activity could be observed during the temperature experiments. When temperature was raised to $20^{\circ} \mathrm{C}$, fish started to show stressed behaviour and swam up from the bottom into the water column. After further elevation to 23 to $24^{\circ} \mathrm{C}$ all fish remained inactive at the bottom of the tank. However, the day after exposure to high temperature all fish behaved normally and began feeding again. For unknown reasons, only 2 out of 30 specimens of the experimental group 1 survived the temperature trial. The survival rate in all other temperature experiments ranged between 95 and $100 \%$.

Well-defined hyaline zones were formed only in otoliths of plaice exposed to temperatures of 25 to $27^{\circ} \mathrm{C}$ for $5 \mathrm{~h}$ (Table 3). Hyaline rings induced by high temperatures were in every case much thinner than those resulting from starvation or UV-B radiation. SEM examination of prepared otoliths revealed that exposure to temperatures above $25^{\circ} \mathrm{C}$ for $5 \mathrm{~h}$ affected the calcium carbonate/otolin rate of only 2 to 3 daily increments, starting on the day after exposure.

\section{UV-B radiation}

Increment formation was more strongly affected by the exposure to high cumulative doses of UV-B radiation. Examination under a stereomicroscope revealed well-defined hyaline zones in otoliths of all fish irradiated with UV-B (Table 3). No difference with regard to the formation of hyaline zones in the otoliths could be observed between pseudoalbinos and normally pigmented specimens. The prominence of hyaline zones was positively correlated with the cumulative dose of UV-B radiation applied (Table 3 ). In all irradiated fish, the number of altered daily increments varied from 6 to 12. All irradiated fish suffered from sunburn. The burns were clearly visible as epidermal necroses within $24 \mathrm{~h}$ after exposure. Moreover, histological examinations of the dorsal skin of low-irradiated $\left(50 \mathrm{~mJ} \mathrm{~cm}^{-2}\right)$ specimens revealed cellular changes characteristic of sunburn damage (Alistair M. Bullock, Dunstaffnage
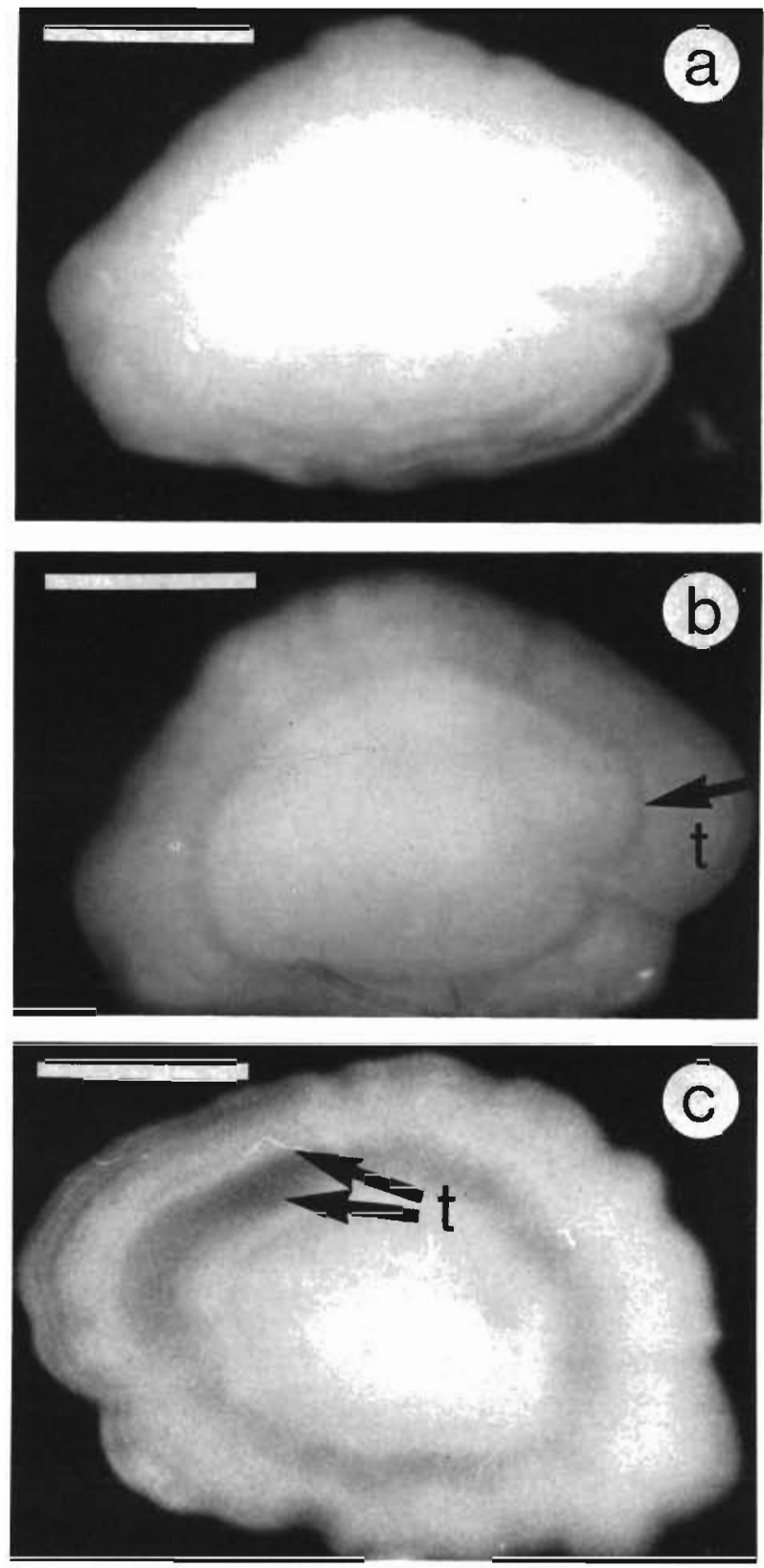

Fig. 1. Pleuronectes platessa. Otoliths of juvenile plaice viewed through a stereomicroscope. Bars $=100 \mu \mathrm{m}$. (a) Typical sagitta from control group. (b) Sagitta of a juvenile starved for 7 d. (c) Sagitta of a juvenile exposed to UV-B radiation (100 $\mathrm{mJ} \mathrm{cm}^{-2}$ ). t: hyaline zone

Marine Research Laboratory, Oban, Scotland, pers. comm.). During exposure and the first, in some cases even the second day, fish activity and feeding were strongly reduced. Increasing mortalities were recorded with increasing cumulative doses of UV-B. Examination of otoliths in SEM revealed deposition of 6 to 12 altered daily increments (Table 3 ), beginning on the first day after exposure (Fig. 2). 

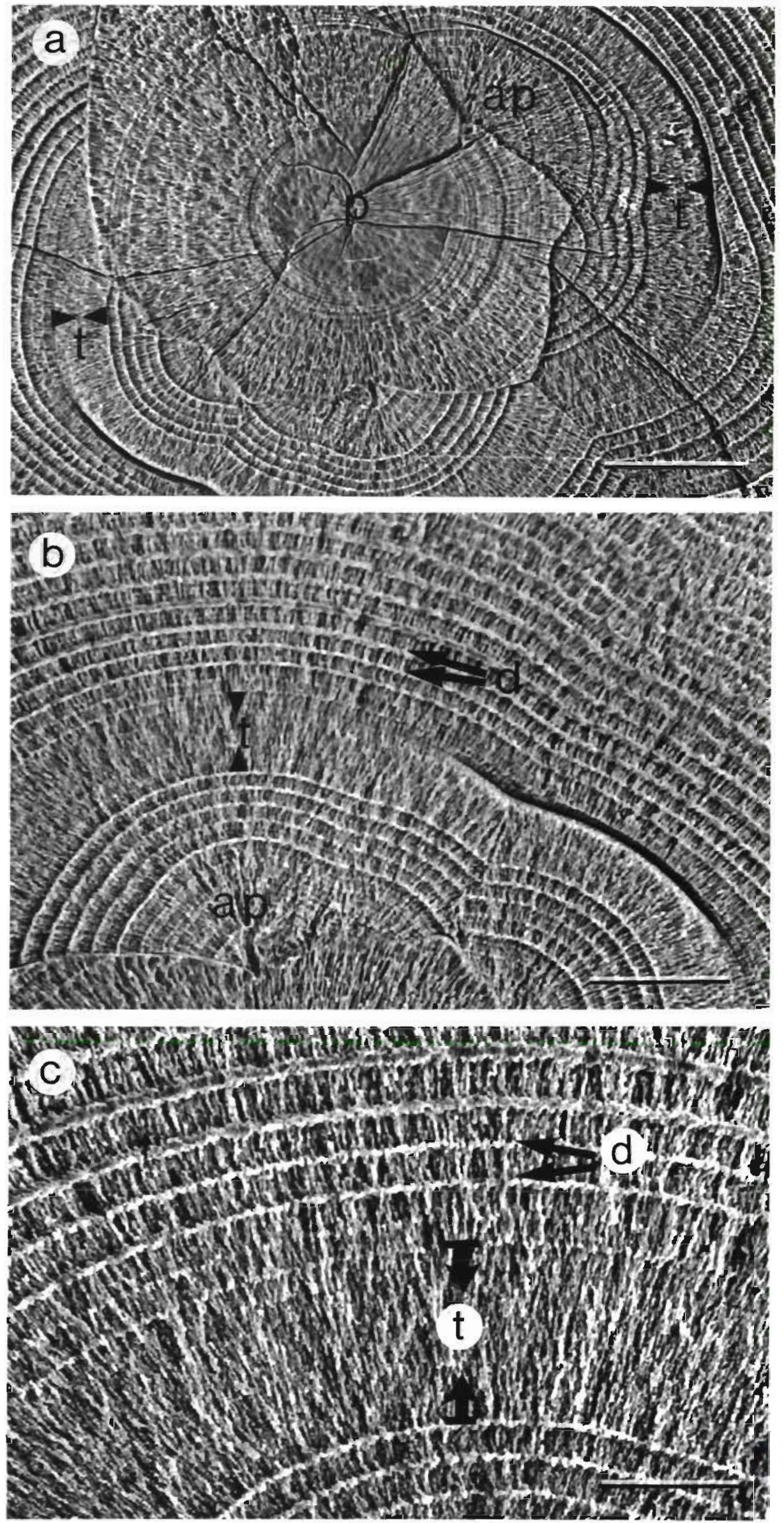

Fig. 2. Pleuronectes platessa. Daily growth patterns in the sagitta of a juvenile plaice exposed to UV-B radiation $\left(100 \mathrm{~mJ} \mathrm{~cm} \mathrm{~cm}^{-2}\right)$ viewed in a SEM. In (a), (b), and (c) the hyaline zone is viewed under different magnifications. Bars $=34,21$, and $10 \mu \mathrm{m}_{\mathrm{i}} \mathrm{t}$ hyaline zone, p: primordium, ap: accessory primordia, d: daily increment 


\section{Starvation}

A well-defined hyaline zone could also be detected in otoliths of all 10 newly settled plaice subjected to starvation for $7 \mathrm{~d}$ (Fig. 1b). SEM examination revealed the deposition of altered daily growth increments to start on the second or third day of the starvation period, and the number of affected increments to vary between 5 and 6 (Table 3). Moreover, a similar decrease in fish activity as already described for the temperature and UV-B radiation experiments could be observed in the first days of food deprivation. It became more evident during the last days of starvation.

It is important to note that not the number but rather the consistency and, to some degree, the width of daily increments was affected. High temperature, UV-B radiation, and starvation do not invoke cessation of the daily increment formation.

\section{DISCUSSION}

The occasional occurrence of a hyaline ring close to the nucleus in sagittae of plaice was first described by Maier (1908). He stated that in some cases it was only visible after slight grinding. In the North Frisian Wadden Sea, these hyaline zones can be found not only in juvenile plaice, but also in flounder Platichthys flesus and sole Solea solea (Berghahn 1984). Lammert (1971) mentioned similar formations in the otoliths of adult sole. In the Wadden Sea - a main nursery ground for North Sea plaice, sole and flounder - many of the postlarvae settle on the submerged tidal flats. During the first days to weeks of their stay in the nursery, postlarvae can be found in high densities in residual water on the tidal flats during low tide (Bergman et al. 1976, Berghahn 1983). During the day, solar radiation quickly warms up the water in the pools. Thus, flatfish postlarvae are exposed to high temperatures of sometimes more than $32^{\circ} \mathrm{C}$ and UV-B radiation exceeding (Dehne, Deutscher Wetterdienst, Meteorologisches Observatorium Hamburg, pers. comm.; Berghahn unpubl. data) the cumulative doses (63 $\left.\mathrm{mJ} \mathrm{cm}^{-2}\right)$ known to induce sunburn in flatfish (Bullock 1982). These conditions can cause mortality (Berghahn 1983) and pathological effects in the epidermis akin to sunburn in the field (Berghahn 1984). On warm, cloudless days when low tide occurs around mid-day, extreme water temperatures can result in a mass exodus of juvenile flatfish through drainage gulleys on the exposed flat down to the main channels. At the same time, many of the tidal pools can become death traps for the postlarvae. They have a chance only if they survive until the tide comes in or the sky clouds over (Berghahn 1983). Recovery from this stress can be linked with a period of starvation, which can be amplified by unsuitable food conditions (Berghahn 1987).

In this study, such formations in the otoliths could be artificially induced by a rapid rise in temperature, high cumulative doses of UV-B radiation or starvation. Consequently, the formation of hyaline zones in the field can be attributed to the action of extreme environmental conditions as described above.

\section{Temperature}

In previous laboratory experiments based on daily increment analysis in otoliths, water temperature was found to be a primary factor in growth of larval and juvenile plaice (Karakiri \& von Westernhagen 1989). According to these experimental data, rearing temperature directly influences the otolith increment width. However, exposure of young plaice to extremely high temperature for a short time affected increment width to a lesser degree than starvation. Only exposure to $27^{\circ} \mathrm{C}$ for $5 \mathrm{~h}$ induced slight hyaline rings consisting of 2 to 3 alterated increments. It should be noted, however, that under natural conditions in the Wadden Sea a rapid rise in temperature can occur in the tidal pools on successive days, since shallow residual waters on the tidal flats cool down considerably as soon as the sun goes (Berghahn 1983). Consequently, pooldwellers can be exposed to high water temperature more than once within short time intervals, which was not tested in the experiments.

\section{UV-B radiation}

Among the conditions tested, high cumulative doses of UV-B radiation had the strongest effect on otolith structure of plaice juveniles. Although sunlight is of vital importance in growth of animals and plants, prolonged radiation may be harmful (Bullock 1982, Siebeck 1983). According to Jerlov (1968), UV-B can penetrate clear water regardless of ionic composition, with $10 \%$ of the initial UV-B radiation at the surface penetrating to a water depth of $15.4 \mathrm{~m}$. In coastal waters the same reduction can already be detected at a water depth of $0.66 \mathrm{~m}$ (Zanefeld 1975). Due to the high natural turbidity of the water in the Wadden Sea (Hikkel 1984), transmission for UV-B is normally much lower still. However, in shallow tidal pools turbidity rapidly decreases, unless maintained by strong winds (Berghahn 1983). In the experimental tanks transmission for UV-B radiation was reduced to $18 \%$ at a water depth of $5 \mathrm{~cm}$ only. This reduction was due to dissolved yellow substances and suspended matter in the circulating seawater. 
Of the juvenile plaice used in the experiments, $90 \%$ suffered from pseudoalbinism. Pseudoalbinism, a common phenomenon in artificially raised plaice (Shelbourne et al. 1963), rarely occurs in the field (Berghahn 1984). However, no differences with regard to the formation of hyaline zones in the otoliths could be observed between pseudoalbinos and normally pigmented specimens. Moreover, histological examinations revealed that pigmented postlarvae appear to suffer more severe skin damage than pseudoalbinos (Bullock pers. comm.). This may be explained by the fact that the melanin layer in plaice, as in most temperate species, is located beneath the epidermis within the stratum spongiosum. Consequently, melanin not only acts as a barrier protecting the dermis and underlying tissues, but also reflects UV back through the dermis. The effect of radiation on the otoliths might have been slightly amplified by the observed reduction in feeding during and after irradiation.

\section{Starvation}

Exposure of young plaice to a starvation period of $1 \mathrm{wk}$ induced altered daily increment deposition in the otoliths, easily detectable as hyaline zones during macroscopic examination. Reduced fish activity observed during the starvation period caused a further diminution of the metabolic rate. In this developmental stage shortly after the transition to the bottom-dwelling mode of life, the growth rate was found to be higher under normal conditions with ad libidum food supply (Karakiri \& von Westernhagen 1989), which also implies a high metabolic activity. Altered daily increments appearing as poor-contrast structures under the light microscope similar to the ones from starved plaice were also recorded in otoliths of larval sole Solea vulgaris Quensel, when first feeding of larvae was delayed for a few days or when food deprivation occurred in the subsequent larval stages (Lagardere \& Chaumilion 1988). Although food deprivation rarely occurs in the Wadden Sea (Zijlstra et al. 1982, Berghahn 1987), it is possible that strong solar radiation and high water temperatures in the tidal pools may be followed by reduced fish activity and starvation.

The altered daily increments visible by SEM indicate an alteration of the calcium carbonate deposition rate. In contrast, deposition of organic material, identified as a protein called otolin with $\mathrm{MB}>150000$ (Degens et al. 1969), seems less affected by food deprivation. It is likely that protein synthesis during short starvation periods takes place on the basis of the organism's reserves. On the other hand, diminution of fish activity seems to be followed by reduced calcium uptake through the gills, which correspondingly affects cal- cium concentrations in the plasma and deposition rates in otoliths. The pathway of calcium deposition in fish otoliths via gill uptake and dissolution in plasma was reported by Simkiss (1974), Mugiya et al. (1981), and Campana (1983). The fact that the deposition of altered daily increments in otoliths started as soon as 2 to $3 \mathrm{~d}$ after food deprivation indicates that plasma calcium is relatively low at this developmental stage, while the calcium demand of the organism is rather high. However, this explanation might be too simplistic, since otolith formation is under complex metabolic control.

It is likely that the mechanism leading to altered increments after exposure to high temperature is similar to that described for starvation: for a short time after the treatment ( 2 to $3 \mathrm{~d}$ ) fish inactivity was observed, which may have influenced the calcium uptake rate through the gills. The same seems to be true for the effect of UV-B radiation. The fact that the hyaline rings formed by low-calcium increments after UV-B irradiation were broader than those deposited during starvation indicates that reactions of the immune system may amplify the reduction of calcium transport and deposition rate. UV-B radiation in particular is harmful for newly settled plaice populations in tidal pools.

Hyaline zones in otoliths of 0-group plaice from the North Frisian Wadden Sea are wider than those induced in experiments. Under natural conditions, the factors tested may act more strongly or in combination. Furthermore, other factors such as oxygen deficiencies, algal toxins, diseases or the sieving procedure on shrimping vessels before discard of by-catch might also induce hyaline zones, thereby providing an explanation for the occurrence of multiple hyaline rings in otoliths from field-caught plaice. Otolith microstructure is known to reflect adverse environmental conditions for flatfish such as oxygen deficiencies (Karakiri \& Temming 1988) and hydrological changes in the nursery ground (Koutsikopoulos et al. 1989). In these cases, however, the long duration of extreme conditions seems to have affected both calcium and protein deposition.

Similar hyaline rings surrounding the nuclear area during the fast growth phase have also been described for roundfish such as Anguilla anguilla (Dahl 1967, Moriarty 1973, Deelder 1976). Secondary ring formation in otoliths of Baltic herring Clupea harengus was attributed to migration from warm coastal waters to deeper areas of the Baltic Sea with lower temperature and higher salinity (Rauck 1964). Steffensen (1980) attributed the formation of irregular structures in otoliths of cod Gadus morhua to the transition to the demersal mode of life. However, since such hyaline rings are lacking in subpopulations of flatfish settled in deep water at the border of the Wadden Sea and since multiple rings also occur (Berghahn 1989), it is clear 
that the transition to the bottom-dwelling mode of life alone does not induce the formation of hyaline zones in otoliths of plaice.

The experiments described here revealed that hyaline zones in otoliths of juvenile flatfish are actually biological tags induced by extreme environmental conditions. This should be considered during age determinations of juvenile plaice, sole and flounder from the North Sea, since such hyaline pseudowinter rings could lead to erroneous results. Moreover, the occurrence of these biological tags might be used in field investigations to distinguish populations, spawning areas and distribution of juvenile flatfish from various nursery grounds. Investigations concerning this practical application as well as other factors which might induce hyaline zones are in progress.

Acknowledgements. Thanks are due to $\mathrm{Dr} \mathrm{H}$. von Westernhagen for providing samples of plaice eggs from the southern North Sea. Dr D. Keyser and Mrs E. Bossman assisted in SEM. Dr A. M. Bullock carried out histological examinations of the skin in some of the irradiated fish. The second author was funded by the DAAD (German Academic Exchange Service).

\section{LITERATURE CITED}

Berghahn, R. (1983). Untersuchungen an Plattfischen und Nordseegamelen (Crangon crangon) im Eulitoral des Wattenmeeres nach dem Übergang zum Bodenleben. Helgoländer Meeresunters. 36: 163-181

Berghahn, R. (1984). Zeitliche und räumliche Koexistenz ausgewählter Fisch- und Krebsarten im Wattenmeer unter Berücksichtigung von Räuber-Beute-Beziehungen und Nahrungskonkurrenz. Dissertation, Univ. of Hamburg

Berghahn, R. (1987). Effects of tidal migration on growth of 0group plaice (Pleuronectes platessa L.) in the North Frisian Wadden Sea. Meeresforsch. 31: 209-226

Berghahn, R. (1989). Environmentally induced biological tags in otoliths of 0 -group plaice (Pleuronectes platessa L.) confirmed by daily increment readings. Rapp. P.-v. Réun. Cons perm. int. Explor, Mer 191. 464

Bergman, M., Kuipers, B., Spliethoff, P., Veer, H. van der (1976). Garnalen en krabben als mogelijke predatoren von 0-jahrige school op het balgzand. Visserij 29: 432-438

Bullock, A. M. (1982). The pathological effects of ultraviolet radiation on the epidermis of teleost fish with reference to the solar radiation effect in higher animals. Proc. R. Soc Edinb. 81B: 199-210

Campana, S. E. (1983). Calcium deposition and otolith check formation during periods of stress in coho Salmon, (Oncorhynchus kisutch). Comp. Biochem. Physiol. 75A: $215-220$

Dahl, J. (1967). Some recent observations on the age and growth of eels. In: Proc. 3rd British Coarse Fish Conf. Liverpool, and Angling Times, Peterborough, p. 48-52

Deelder, C. L. (1976). The problem of supernumerary zones in otoliths of the European eel (Anguilla anguilla L.): a suggestion to cope with it. Aquaculture 9: 373-379

This article was submitted to the editor
Degens, E. T., Deuser, W. G., Haedrich, R. L. (1969). Molecular structure and composition of fish otoliths. Mar Biol. 2: 105-113

Hickel, W (1984). Seston in the Wadden Sea of Sylt (German Bight, North Sea). Neth. Inst. Sea Res. Publ. Ser 10: 113-131

Jerlov, N. G. (1968). Optical oceanography. Elsevier Press, London

Karakiri, M., Temming, A. (1988). Effects of oxygen deficiency in the Kiel Bight on the daily increment formation in otoliths of common dab, Limanda limanda L. Verh. dt. zool. Ges. 81.323 (in German)

Karakiri, M., Westernhagen, H. von (1988). Apparatus for grinding otoliths of larval and juvenile fish for microstructure analysis. Mar Ecol. Prog. Ser 49: 195-198

Karakiri, M., Westernhagen, H. von (1989). Daily growth patterns in otoliths of larval and juvenile plaice, Pleuronectes platessa L.: influence of temperature, salinity and light conditions. Rapp. P.-v. Réun. Cons. int. Explor. Mer 191 376-382

Koutsikopoulos, K., Karakiri, M., Desaunay, Y., Dorel, D. (1989). Response of juvenile sole Solea solea L. to abrupt environmental changes in the Bay of Vilaine (Biskaya). Rapp. P.-v. Réun. Cons. int. Explor. Mer 191. 281-286

Lagardere, F., Chaumillon, G. (1988). Influence d'une première alimentation differée sur la croissance des larves de sole, Solea vulgaris, et l'accroissement de leurs otolithes. C. R. Acad. Sci, Paris 306 (III): 601-607

Lammert, H. (1971). Untersuchungen über die ostfriesische Seezungenfischerei im Jahre 1969. M.Sc. thesis, Univ. of Hamburg

Maier, H. N. (1908). Beiträge zur Altersbestimmung der Fische. 1. Allgemeines. Die Altersbestimmung nach den Otolithen bei Scholle und Kabeljau. Wiss. Meeresuntersuch. (Abt. Helgoland) N.F. 8 (1): 57-111

Moriarty, C. (1973). A technique for examining eel otoliths. J. Fish Biol. 5: 183-184

Mugiya, Y., Watabe, N., Yamada, J., Dean, J. M., Dunkelberger, D. G., Shimuzu, M. (1981). Diurnal rhythm in otolith formation in the goldfish, Carassius auratus. Comp Biochem. Physiol. 68A: 659-662

Rauck, G. (1964). Die Struktur der Otolithen des Ostseeherings als Hilfsmittel bei der Trennung biologischer Gruppen. Dissertation, Univ. of Kiel

Shelbourne, J. E., Riley, J. D., Thacker, G. T (1963). Marine fish culture in Britain. 1. Plaice rearing in closed circulation at Lowestoft, 1957-1960. J. Cons. perm. int. Explor. Mer 28: $50-69$

Siebeck, O. (1983). UV als Umweltfaktor in aquatischen Biotopen. Verh. Ges. Ökol. Göttingen 10: 583-589

Simkiss, K. (1974). Calcium metabolism of fish in relation to ageing. In: Bagenal, T B. (ed.) Ageing of fish. Unwin Bros. Ltd., London, p. 1-12

Steffensen, E. (1980). Daily growth increments observed in otoliths from juvenile East Baltic cod. Dana $1 \quad 29-37$

Zanefeld, J. R. (1975). Penetration of ultraviolet radiation into natural waters. In: Impacts of climatic change on the biosphere. Dept. of Transport USA. Climate impact assessment program: Monograph 5, Washington D.C., p. 108-166

Zijlstra, J. J., Dapper, R., Witte, J. Ij. (1982). Settlement, growth and mortality of post-larval plaice (Pleuronectes platessa) in the western Wadden Sea. Neth. J. Sea Res. 15: $250-272$

Manuscript first received: March 6, 1990

Revised version accepted: August 9, 1990 